\title{
THE UNIVERSITY OF WISCONSIN-MILWAUKEE
}

\author{
MILWAUKEE, WISCONSIN 53201
}

CENTER FOR GREAT LAKES STUDIES Director, C. H. Mortimer.
Contract Title: "INVESTIGATION OF THE INFLUENCE OF THERMAL DISCHARGE FROM LARGE ELECTRIC POWER STATION ON THE BIOLOGY AND NEAR-SHORE CIRCULATION OF LAKE MICHIGAN. - PART A: BIOIOGY," UNDER THE DIRECTION OF DR. A.M. BEETON, OF THE CENTER FOR GREAT LAKES STUDIES, THE UNIVERSITY OF WISCONSIN-MILWAUKEE.

Report Type \& Period: Quarterly; I January 1972 - 31 March 1972

The following progress has been made on the intended areas of study outlined in previous reports:

1) Monthly investigations of the general area around the Oak Creek plant and a northern control area have now been carried out for six months. Chemical analyses have been completed for these sampling periods. Zooplankton and phytoplankton analyses are near completion. The information gathered from these analyses has been carefully examined for the purpose of evaluating the past six months' investigations. The conclusion reached was that monthly sampling is no longer necessary, since a good understanding of the general area has already been obtained. For the next four months these investigations will be conducted on a seasonal basis. Two more sampling periods are scheduled.

2) Investigation of the area immediately surrounding the power plant proved to be logistically impossible during the winter months. No nearby launch facilities were open and the power company's boat was out of operation during this period. These problems also curtailed the phytoplankton sampling of the intake and plume waters. These investigations will resume when weather conditions permit.

3) Construction of the incubator to be used for primary productivity measurements was completed in March. Preliminary trials of the equipment have been carried out. The equipment has subsequently been installed in the power plant for easy access to the water systems desired. Actual investigations of primary production will begin in April.

4) Periodic investigations of the water chemistry of the intake and discharge waters is continuing.

5) The experimental design for the investigation of the thermal requirements of planktonic invertebrates has been formulated. This investigation is scheduled to begin early this summer.

The following new area of study has been planned:

The data collected from the monthly investigations described above have shown that it is necessary to know what factors other than waste heat may be influencing the aquatic environment around the Oak Creek power plant. To determine this, a synoptic chemical survey of the area between Milwaukee and Racine, Wisconsin, is planned. It will be conducted on a seasonal basis beginning the third week of April.

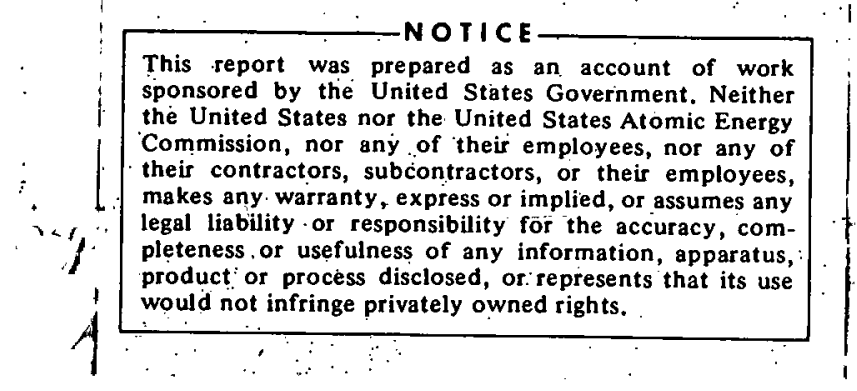




\section{DISCLAIMER}

This report was prepared as an account of work sponsored by an agency of the United States Government. Neither the United States Government nor any agency Thereof, nor any of their employees, makes any warranty, express or implied, or assumes any legal liability or responsibility for the accuracy, completeness, or usefulness of any information, apparatus, product, or process disclosed, or represents that its use would not infringe privately owned rights. Reference herein to any specific commercial product, process, or service by trade name, trademark, manufacturer, or otherwise does not necessarily constitute or imply its endorsement, recommendation, or favoring by the United States Government or any agency thereof. The views and opinions of authors expressed herein do not necessarily state or reflect those of the United States Government or any agency thereof. 


\section{DISCLAIMER}

Portions of this document may be illegible in electronic image products. Images are produced from the best available original document. 